\title{
Analysis of the Effectiveness of Existing Niger Seed Market Channels in Selected Primary Agricultural Multipurpose Cooperatives in Horo Guduru Wollega Zone, Oromia (page 43-60)
}

\author{
Merga Futasa Begna \\ $\mathrm{PhD}$ Scholar and Ambo University Lecturer \\ at Ambo University, Ethiopia
}

\begin{abstract}
Agriculture in Ethiopia remains to be the key sector. A recorded literature suggests that one form of smallholder farmers' commercialization is through production of cash crops like niger crop is conceivable to be the major source of export revenue and contribute to livelihoods diversification and poverty alleviation by directly increasing the farm household's income earning potential. The objective of the study was, to analyze the effectiveness of existing niger seed market channels cooperatives in the study area. Multi- stage sampling technique was used to select Abay Chomen District and the four primary cooperatives from the sample frame and by using Kothari formula sample of 145 respondents were drawn from four primary agricultural multipurpose cooperatives in the study area. The analysis of the study was based on both Primary and secondary data sources that combined qualitative and quantitative data which were collected from the members of the sampled cooperatives. The data were collected through the survey interview schedule questionnaires, checklist for FGDs and key informant interviews. For the realization of the stated objectives the study included variables like. The data was analyzed using descriptive statistics using SPSS version 16.0 and $\chi^{2}$ of association were used to test the association between the independent and dependent variables. Based on the main findings due to a number of factors that limit the niger seed market channels in cooperatives, $37(25.5 \%)$ of the respondents were reported that the existing niger seed market channels in cooperatives is effective whereas $108(74.5 \%)$ of the opined that ineffective. The result of the descriptive statistics showed that from the truncated descriptive statistics and cross tabs result shows that asset endowments like farm land and size of oxen owned are the major influencing factors of the existing niger seed market channels' effectiveness in cooperatives the study area.
\end{abstract}

Keywords: Niger seed , multipurpose cooperatives , effectiveness, market channel

DOI: $10.7176 / \mathrm{JAAS} / 74-01$

Publication date:July $31^{\text {st }} 2021$

\section{Background Of The Study}

According to CSA (2007), in Ethiopia maize, wheat, teff, barely, niger seed and Sesame are the main cereal crops in the country. Niger seed in Ethiopia is widely grown by smallholder farmers on fragmented land holdings. It is the leading oil crop in production and area coverage in the oil seeds category. Niger seed in Ethiopia is cultivated mainly for the production of edible oil and direct consumption fried and mixed with sunflower seed. The pressed cake from oil extraction is used for livestock feed especially in and around cities and large fattening and dairy farms. Niger seeds contain around $40 \%$ oil and about $20 \%$ protein. Getinet and Sharma report that Niger oil has a fatty acid composition typical for other Composite family oils, such as safflower and sunflower. Fortunately, oil produced by crops in the Composite family is considered to be among the healthier selections. Niger seed oil contains linoleic acid as the primary fatty acid (75-80\%), followed by palmitic and stearic acids (7-8\%) and oleic acid (5-8\%), although Indian Niger oil is reportedly higher in oleic acid (25\%) and lower in linoleic acid (55\%). Described as having a "nutty taste and a pleasant odour," the edible oil is the main product from niger seed in both Ethiopia and India. Various methods and equipment are used to press the oil, including "small cottage expellers and large oil mills." And besides cooking purposes, It can also substitute for sesame oil for pharmaceutical purposes and can be seed for soap making (Getinet and Sharma 1996, 18, as cited in Amanuel F. 2013).The oilseeds sector is one of Ethiopia's fastest growing and important sectors, both in terms of its foreign exchange earnings and as a main source of income for over three million Ethiopians. It is the second largest source of foreign exchange earnings after coffee. Study reports indicate that Ethiopia is among the top-five producers of sesame seed, linseed and Niger seed (Wijnands et al. 2008, cited in FCA,2007). The potential for further growth, both in terms of quantity and quality, through improved production techniques and productivity factors niger seed is considered to be great.

The sub-sector has diverse and significant constraints. Marketing and distribution of oil seeds are mainly done by small and medium scale traders with poor marketing facilities, especially for collection, storage and transportation, which cause high post-harvest losses. The marketing channel is long, with many intermediaries adding little value to the final product, with high transaction costs being incurred. Lack of access to packaging 
services, poor access to financial services, and poor vertical and horizontal collaboration within, as well as external to the channel, all negatively impact on the industry. This has been a cause for substantial income loss of the majority of farmers. Maize, wheat, teff, barely, niger seed and Sesame are the main cereal crops grown in Oromia Regional state. Among eighteen zones in Oromia, Horo Guduru Wollega is one of the known zones in growing cereal crops in general and niger seed in particular.

This is due to the fact that cooperatives can reduce transaction costs and improve the bargaining power of smallholder farmers' visa-a-vis increasingly integrated markets (as cited by Nicola, 2009). In line with this, agricultural cooperatives particularly marketing cooperatives are advocated by the Government of Ethiopia as the main pillars of development and key market institutions in its Agricultural Development Led Industrialization Strategy. This plan aims to unlock Ethiopia's agricultural growth potential by providing a better institutional environment for integrating smallholder farmers into international market (FDRE, 2001). Market failures have mainly been in the form of exploitation of individual farmers or producers largely by market intermediaries resulting in remunerative prices not reaching the individual producers. Distortions in supply channels are mainly through market intermediaries who get into a win-win situation for themselves both from the supply of raw material or agricultural inputs to the disposal of the produce. Global studies on agricultural produce markets have revealed that supply chain ineffectiveness contribute to as much as $30-50 \%$ loss of revenue to the producer (Nimble, 2005:2). And studies has been done before in this study area in this specific topic. Therefore, to fill the gap this study focused on an evaluation of the of existing niger seed market channels' effectiveness in selected primary agricultural multipurpose cooperatives in the study area.

\section{Descriptive Analysis Result and Discussion}

Evaluation of the Effectiveness of Existing Niger Seed Market Channels in Selected Primary Cooperatives Thus, evaluation was done through analysis of the demographic, with a main focus in terms indicators of services offered by the market channels in relation with the niger seed market channels' effectiveness in selected cooperatives. The effectiveness of niger seed marketing channels in cooperatives was evaluated by considering the different service indicators as measurements that the channels have offered in the market in order to maximize both cooperative member producers and consumer expectation.

\section{Results of Frequency Analysis of Effectiveness of Existing Niger Seed Market channels Economic Factors \\ Dividend}

Cooperatives are business organizations owned and controlled by their members who use them. When the cooperative operates for the benefit of members, it obtains revenue from members' participation that can be allocated for the reserve fund, social services, expansion of activities, training and education, incentive of committees and patronage dividend as per the Cooperative Proclamation No.147/98 and Amendment Proclamation No.402/2004. Patronage dividend distribution is one of the promotional strategies that can encourage members' participation in cooperative activities. It was assumed that as well as timely dividend distribution, resulting in active participation of members to make effective cooperative market channels. Most of the farmers revealed dividend payment as the most influential reason for joining agricultural cooperatives and for effective service seeking through cooperatives.

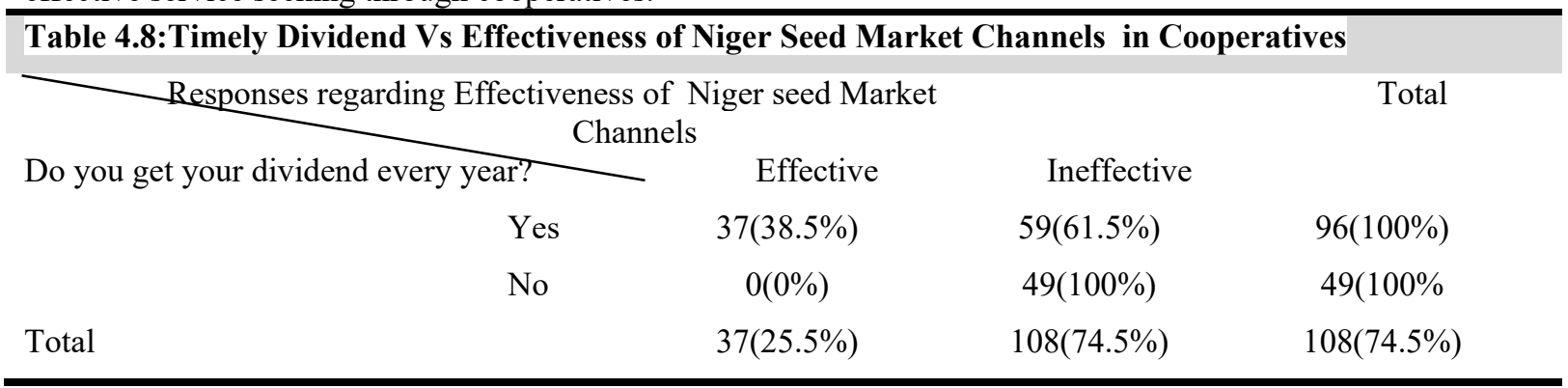

Chi- square test - significant at $1 \%$

Source: Computed from Survey data, 2014

The cross tab result indicates that among the 96 respondents who received dividend 37(38.5\%) reported niger seed market channel in cooperatives as effective. On the other hand all the 49 respondents $(100 \%)$ of them who did not receive dividend reported ineffective. The reasons cited for untimely dividend include: poor transaction recording system by the elected committees, corruption practices, belated auditing and audit report preparation. The corrupt practices refer to the dividend distribution based on number of share of members' rather than consideration of members' market participation as well. the members of the management committee gets a sizeable slice of the portion of dividend to be earmarked for members' business participation by appropriating 
that amount to their accounts, which is out rightly against the bylaws, internal regulations, principles and values of cooperatives. The key informants' discussion result also reflected the same idea. According to chi-square test of association, there is statistically significant relationship between dividend payment and effectiveness of niger seed market channels in cooperatives at $99 \%$ confidence level $(p$-value $<0.01)$.

\section{Market Factors}

\section{Distance from Cooperative Market Center}

As the crops are bulky, the proximity to the road will matter. The farmers need to produce and participate in the farming of marketable commodities.

Table 4.11 Distance from cooperative market vs Effectiveness of niger seed market channels

\begin{tabular}{|c|c|c|c|}
\hline Responses regarding Market $\mathrm{C}$ & nel Effectiven & & Total \\
\hline How far is your house from the cooperative? & Effective & Ineffective & \\
\hline $1-4 \mathrm{KM}$ & $36(43.4 \%)$ & $47(56.6 \%)$ & $83(100 \%)$ \\
\hline $5-7 \mathrm{KM}$ & $1(1.6 \%)$ & $61(98.4 \%)$ & $62(100 \%)$ \\
\hline Total & $37(25.5 \%)$ & $108(74.5 \%)$ & $145(100 \%)$ \\
\hline
\end{tabular}

Chi-square test ...............-1.93, $\mathrm{P}=0.09$

Source: Computed from Survey data (2014)

Note:Significant at $10 \%$ of Probability Level

The cross tab result indicates that $36(43.4 \%)$ of the respondents who were nearby (1-4 kilometer) the cooperative were of the opinion that the market channels in cooperatives are effective; whereas, 61(98.4\%) respondents from distant areas (5-7 KM) reported ineffective. The respondents who are far from cooperatives, when asked revealed that most of them are nearer to farmer traders and Fincha town rather than the cooperative market center. In addition to distance, there is difficulty of well-laid roads to bring their produce to cooperative market center. The chi-square test of association shows that there is statistically significant inverse relationship in between distance from cooperative market and effectiveness of niger seed market channels in cooperatives at $90 \%$ confidence level $(\mathrm{p}$-value $=0.09)$

\section{Mode of Selling}

Mode of selling refers to selling of niger seed to cooperatives for immediate cash or on credit basis. It was assumed that if the cooperatives immediately pay cash for the farmers' produce; the members sell their niger seed produce through cooperatives rather than non-cooperative channels, which signifies that the niger seed market channels in cooperatives are more effective.

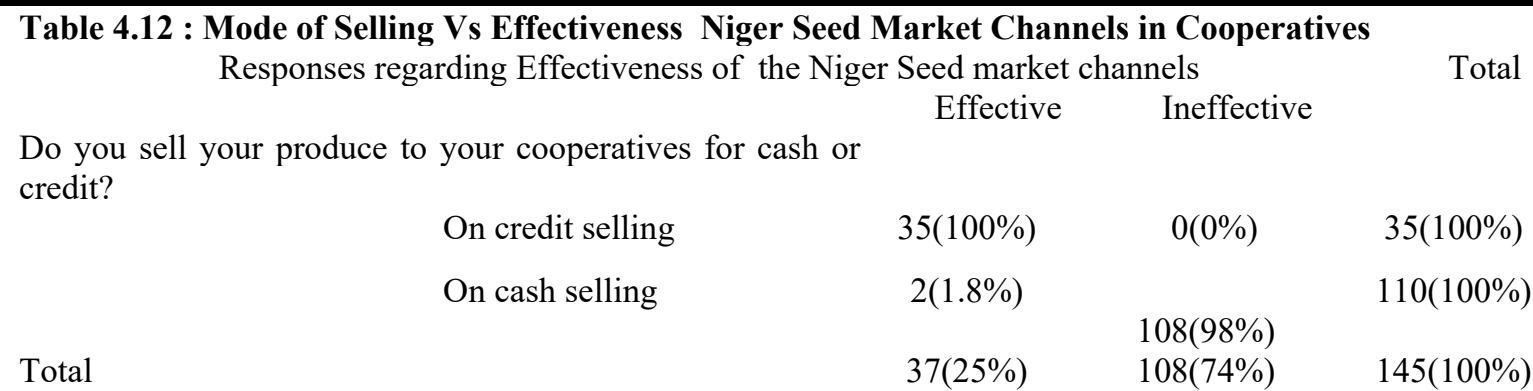

Chi- square test.......1.347 $\mathrm{P}=0.000 *$ Figures in bracket refers Percentage to Row total

Source: Computed from Survey data (2014)

Note: Significant at $1 \%$ of Probability Level

Usually, the cooperatives are not immediately paying cash to members' produce as is the case with noncooperative channels. As per the result of the survey shown in table 4.12, for all the 35 respondents who sold on credit, the niger seed market channels in cooperatives are effective. Among the rest 110 respondents did not opt credit sales, most of them (108 ie. $98.2 \%$ ) expressed ineffective, since there is no room for their preference to sell for immediate cash to meet out their immediate needs. Inadequate liquid cash holding and shortage of capital by the cooperative were the reason cited for credit selling mode, and as a result, farmers' preferred to sell their niger seed produce through non- cooperative market channels in the study area. Focus group discussions and key informants interviews also revealed the same. Farmers indicated their appreciation for the up-front and cash payment by private traders. Hence, this has been cited as one of the reasons for not using always cooperatives as their marketing channel. According to chi- square test of association there is statistically significant positive relation between mode of selling and effectiveness of niger seed market channels at $(\chi 2=1.347, \mathrm{df}=1$ and $\mathrm{P}$ value $<0.01)$. 
INSTITUTIONAL FACTORS

Member Trust on their Cooperatives

Table 4.13:Member trust Vs Effectiveness of Niger Seed Market Channels in Cooperatives

Responses regarding Effectiveness of the Niger Seed Market

Total

Channels

Do you trust your cooperative?

Effective

Ineffective

$\begin{array}{ccccc} & \text { Yes } & 37(92.5 \%) & 3(7.5 \%) & 40(100 \%) \\ \text { Total } & \text { No } & 0(0 \%) & 105(100 \%) & 105(100 \%) \\ & & 37(25.5 \%) & 108(74.5 \%) & 145(100 \%)\end{array}$

Chi- square test........1.199, $\mathrm{p}=0.000 *$ Figures in bracket shows Percentage to Row total

Source: Computed from Survey data (2014) * Significant at 1\% ofProbability Level

Member trust is the most important factor for effectiveness of cooperatives, since trusted cooperatives are able to attract business-patrons. More the trust, more the business patronage, so also the effectiveness of various business activities, including the service provision by market channels operating. As presented in table4.13, among the total of 40 who have trust on their cooperatives, 37(92.5\%) of the them affirmed that niger seed market channel in cooperativeswas effective, and the reason cited was they were benefitted by the credit extended by the cooperative, and so is their mutual patronage to the cooperative in trusting and selling through it for credit. But all the $105(100 \%)$ who lacked trust on their cooperatives said ineffective and attributed reasons like: malpractices such as corruption, and weight cheating. Those respondents said effective market channel were also asked and they replied that they have received credit from their cooperatives and selling their niger produce through cooperatives. The chi- square result shows that there is statistically significant positive relation between members' trust and effectiveness of niger seed market channels in cooperatives at $(X 2=1.199, \mathrm{Df}=1$ and p-value $<0.01)$.

\section{Access to Training}

Training is the opportunity to learn new, and being capacitated. The objective of training here is to improve the knowledge and skill and /or professionals' competencies of leaders and employees in cooperatives. Training has specific goals of improving one's capability, capacity, and performance and strengthens the linkage between members and the cooperatives. It is plays very crucial role in the niger seed market channel as it influences its effectiveness.

Table 4.14:TrainingVs Effectiveness of Niger Seed Market Channels in Cooperatives

\begin{tabular}{|c|c|c|c|c|}
\hline & Responses & regarding Effectiveness of the & Niger seed Market & Total \\
\hline Does your cooperative & & Effective & Ineffective & \\
\hline & Yes & $31(100 \%)$ & $0(0 \%)$ & $31(100 \%)$ \\
\hline & No & $6(5.3 \%)$ & $108(94.7 \%)$ & $114(100 \%)$ \\
\hline Total & & $37(25.5 \%)$ & $108(74.5 \%)$ & $145(100 \%)$ \\
\hline
\end{tabular}

Source: Computed from Survey data (2014)

Note: Significant at $1 \%$ of Probability Level

The survey result in the table 4.14 indicates that all of them who had access to training contribute for effective niger seed market channels in cooperatives.Of the 114 who were not having access to training,108(94.7\%) reported that niger seed market channel in cooperativesareineffective. The focus group discussion also signifies the above idea and they reported that the limited capacity of leaders remains the critical constraints to the market development of the cooperatives and the member farmers who were elected to be the board of directors of their cooperatives often have a low level of cooperative knowledge due to lack of training which leads to ineffective market channels in cooperatives. The chi-square test result reveals that there is statistically significant relationship between training and effectiveness of niger seed market channels in cooperatives at $(\chi 2=83.94$, $p$-value $<0.01)$.

\section{Access to Credit Services}

In agriculture, credit is expected to facilitate to improve agricultural technology, transformation of traditional 
agricultural practices, mitigate adverse conditions (drought, crop failure and disease and price uncertainties) and improve conditions of physical and human capital.In addition, credit increases farm efficiency, the flexibility of farmers' decisions, and helpsattain economiesof scale in production, and consumption smoothing (Edilegnaw, 2000, cited in Abebe, 2013).

Table 4.16:Credit Service Vs Effectiveness of the Niger Seed Market Channelsin Cooperatives

Do you have credit accessibility from your cooperative?

$\begin{array}{ll} & \text { Yes } \\ & \text { No } \\ \text { Total } & \\ \begin{array}{l}\text { From where did you } \\ \text { get credit? }\end{array} & \begin{array}{l}\text { From cooperative } \\ \text { Private traders } \\ \text { Microfinance }\end{array} \\ \text { Total } & \end{array}$

Effective

$$
\begin{array}{r}
37(92.5 \%) \\
0(0 \%) \\
37(25.5 \%)
\end{array}
$$
$37(25.5 \%)$
Ineffective

$\begin{array}{rr}3(7.5 \%) & 40(100 \%) \\ 105(100 \%) & 105(100 \%) \\ 108(74.5 \%) & 145(100 \%) \\ 40(100 \%) & 40(100 \%) \\ 38(50.7 \%) & 75(100 \%) \\ 30(100 \%) & 30(100 \%) \\ 8(74.5 \%) & 145(100 \%)\end{array}$

$\mathrm{X} 2 \ldots \ldots \ldots \ldots \ldots \ldots \ldots \ldots \ldots+17$

$\mathrm{p}=0.000 *$ Figures in bracket Percentage to Row total

Source: Computed from Survey (2014)

Note: Significant at $1 \%$ probability level

The cross tab result indicates that among the 40 respondents who had access for credit from their cooperatives, 37 (92.5\%) opined that niger seed market channel was effective; and hence they fully sold their niger seed produce through their cooperatives, and all the 105 respondents who did not have access to credit from their cooperatives opined ineffective. The reasons attributed include: inability of cooperatives to give credit due to poor capital base. And if at all given, it falls short of the demand and the favored are the kith and kin of the members of the management bodies, thereby violating the basic tenets of cooperatives. According to FGD and key informants 'interview, there was repayment problem, and was not considered so serious since lending was based on nepotism, thereby putting cooperatives at permanent tenterhooks for further lending the needy. In responding to the purpose of credit they require, they revealed that it is opted for purchasing fertilizers, for to pay the rented land, to purchase oxen and for family and school expenses. As presented in table 4.16, only 40(23.6\%) of them have taken credit from their cooperatives while, 38(50.7\%), $30(20 \%)$ of them have had from private traders and micro finance like Oromia credit and saving share company, Wasasa company respectively. The computed chi-square test of association revealed that there was statistically positive relationship between credit and effectiveness of niger seed market channels in cooperatives at $99 \%$ confidence level $(X 2=1.17, \mathrm{df}=2, \mathrm{p}$-value $<0.01)$

\section{LEGAL FACTORS}

\section{Professional Management}

Problem of professional management in selected cooperatives hinders effective market channels in cooperatives. Well-functioning cooperatives often have professional, fulltime managers capable of maintaining effective market channels. Evidence from the world highlights strong management of cooperatives as the most important determinants of success of the cooperative market channels. International best practices consistently show that well-functioning cooperatives have professionals (World Bank and ILO).

Table4.19:Professional Management Vs Effectiveness of Niger Seed Market Channels in Cooperatives

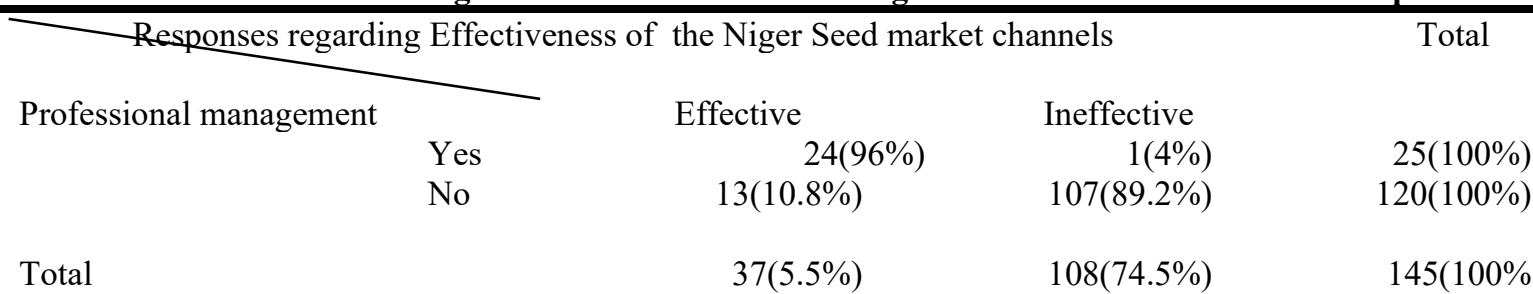

Chi-Square ...........................................

Source: Computed from Survey data $(2014$

Note: Significant at $1 \%$ of Probability Level

The cross tab analysis shows that $24(96 \%)$ of them who witnessed professional management in cooperatives opined that niger seed market channels in cooperatives are effective while $107(89.2 \%)$ of respondents have witnessed that cooperatives were not run by educated professionals management replied 'ineffective'. The reason behind is that, primary cooperatives under the study were not willing and able to hire professionals due to lack of awareness, capital shortage and committee resistance. The study is in accordance 
with the work of Chambo(2009) who outlined that cooperative management in Africa is poor due to inadequate training and extension. So, the selected cooperatives under the study need to hire educated professionals and cultivate right leadership and qualified professional management, so that maintaining effective niger seed market channel in cooperatives, would not be so challenging. The computed chi-square test of association indicates that there is highly statistically significant association between professional and effectiveness of niger seed market channels in cooperatives at $99 \%$ confidence level $(\chi 2=41.683, \mathrm{Df}=1$,p- value $<0.01)$.

\section{Conclusions}

After a thorough analysis of evaluation of the effectiveness of the existing niger seed market channels in selected primary agricultural multipurpose cooperatives in the study area, this study concluded that the effectiveness of niger seed market channel in cooperatives is quite ineffective in providing quality of required services that could make effective market channels in cooperatives and satisfy niger seed farmer producers expectations.

\section{Recommendations}

$>$ One of the crucial factors identified for ineffectiveness of niger seed market channels in cooperatives is untimely payment of patronage dividend to members, as expressed by majority of respondents. They have further added that timely distribution of dividend highly influences their sense of ownership for improving the effectiveness of the market channels in cooperatives. Therefore, the concerned appropriate authorities should take necessary measures to see that cooperatives are paying the patronage dividend to their member patrons on time as well as completion of their annual business audit process prior to that. And the appropriate authority should take in to consideration and enforce.

$>$ Transparency in cooperative activities influences the effectiveness of the market channels: There is a need for better governance in the sampled cooperatives, by being transparent enough in its business operations in relation to signing of contractual marketing agreements, facilitating timely audit services to ensure prompt patronage distribution, in disseminating market information for better coordination of marketing activities of smallholder farmers, if these cooperatives are to enhance the effectiveness of their niger seed market channels. In this regard, the intervention of cooperative committees and promoters are very vital. They should remain exemplary for others in being so transparent in business activities, which could be emulated by other related stakeholders in due course.

\section{Acknowledgments}

At the top of all, I would like to extend my special thanks to the Almighty God for everything of his kindness and for all that he has done for me. My genuine appreciation goes Dr. J.Subramani (ASS. professor), for his constructive comments, encouragement, and for his polite behavior. I take this opportunity to extend my deepest thanks to all people, institutions and to all of my friends who facilitated and showed cooperation when I was collecting data and writing up the paper. Last but not least, "S/r. Desistu Gadissa!" take especial heart full thanks for your heart full love and encouragement in completion of this study. Thank you God bless you all!

\section{References}

Amanuel Fikadu (2013). Analaysis of Effectiveness of Coffee Value chain in sasiga woreda. Ambo, Ethiopia. Unpublished.

CSA(Central Statistical Agency),(2007). Agricultural Sample survey, Volume I, Addis Ababa. Pp.323-327.

FCA (2007). The cooperative development in ethiopia, Federal Cooperative Agency. Addis Ababa, Unpublished

FCA (Federal Cooperative Agency),(2012). Agricultural Cooperatives Sector Development Strategy.

Frank Ratna Kumar, A. Savarimuthu and K.Ravichandran,( 2003). A new World through Cooperatives, Rainbow publications, India.

Getinet, A. and S.M. Sharma.,(1996). Niger, Guizotia Abyssinica (L.f.) Cass. Promoting the conservation and use of underutilized and neglected crops, Institute of Plant Genetics and Crop Plant Research, Gatersleben/International Plant Genetic Resources Institute, Rome.

Guizotia abyssinica Eco crop. Food and Agriculture Organization of the United Nations.http://ecocrop.fao.org/ecocrop/srv/en/cropView? id $=6567$.

ICA (International Cooperative Alliance), (2009). Driving Global Recovery through Cooperatives.

Jari B. (2009). Institutional and Technical Factors Influencing Agricultural Marketing Channel Choices amongst Smallholder And Emerging Farmers in the Kat River.

Kimberly A.Zeuli and Robert Cropp, (2004). Cooperatives: Principles and Practices in the 21st Century. Cooperative Extension Publishing, University of Wisconsin, Medison, USA.

Nimble, (2005). "Cooperative Model: success engine for commodities www.nimble.in accessed on $22 / 12 / 2010$ 
Rehima M., (2006). Analysis of red pepper Marketing: The case of Alaba and Silitie in Research Organization (EARO) SNNPRS of Ethiopia. A M.Sc. Thesis presented to School of Graduate Studies of Haramaya). Page:54. practices in the 21st century. Madison, WI: University of Wisconsin Extension. 